\title{
Exophiala angulospora causes systemic inflammation in Atlantic cod Gadus morhua
}

\author{
Mona Cecilie Gjessing ${ }^{1, *}$, Marie Davey ${ }^{2,3}$, Agnar Kvellestad ${ }^{4}$, Trude Vrålstad ${ }^{1,2}$ \\ ${ }^{1}$ Norwegian Veterinary Institute, Pb 750 Sentrum, 0106 Oslo, Norway \\ ${ }^{2}$ Microbial Evolution Research Group (MERG), Department of Biology, University of Oslo, 0316 Oslo, Norway \\ ${ }^{3}$ Department of Ecology and Natural Resource Management, Norwegian University of Life Sciences, 1432 Ås, Norway \\ ${ }^{4}$ Section of Anatomy and Pathology, Institute of Basic Sciences and Aquatic Medicine, Norwegian School of Veterinary \\ Science, 0033 Oslo, Norway
}

\begin{abstract}
Species of Exophiala are opportunistic fungal pathogens that may infect a broad range of warm- and cold-blooded animals, including salmonids and Atlantic cod. In the present study, we observed abnormal swimming behaviour and skin pigmentation and increased mortality in cod kept in an indoor tank. Necropsy revealed foci of different sizes with a greyish to brownish colour in internal organs of diseased fish. The foci consisted of ramifying darkly pigmented fungal hyphae surrounded by distinct layers of inflammatory cells, including macrophage-like cells. In the inner layer with many hyphae, the macrophage-like cells were dead. We observed no apparent restriction of fungal growth by the inflammatory response. A darkly pigmented fungus was repeatedly isolated in pure culture from foci of diseased fish and identified as Exophiala angulospora using morphological and molecular characters. This species has not been previously reported to cause disease in cod, but has been reported as an opportunistic pathogen of both marine and freshwater fish. Based on the morphology and sequence analysis presented here, we conclude that E. angulospora caused the observed chronic multifocal inflammation in internal organs of cod, leading to severe disease and mortality.
\end{abstract}

KEY WORDS: Macrophages · Capronia coronata $\cdot$ Herpotrichiellaceae $\cdot$ Black yeast

\section{INTRODUCTION}

Even though systemic mycoses are not common in aquaculture, a number of such diseases are described in fish (Roberts 2004). Members of the fungal group commonly referred to as 'black yeasts', more specifically the genus Exophiala (Herpotrichiellaceae, Chaetothyriales), cause both superficial and systemic, sometimes fatal, mycoses in a wide variety of warm- and cold-blooded animals (Langvad \& Pedersen 1985, Otis et al. 1985, Orélis-Ribeiro et al. 2010, Li et al. 2011) including Atlantic cod (Blazer \& Wolke 1979). In fact, Exophiala species are among the most commonly reported agents of systemic mycoses in fish, although the isolations of these species from non-fish substrates such as soil, sediments, nematode cysts, wood, plant material substrates, human hair and nails, and drinking wa- ter (Uijthof et al. 1997, Domsch et al. 2007, S. de Hoog pers. comm.) suggest they are opportunistic pathogens and not restricted to a pathogenic life-history strategy.

Among those Exophiala species reported to cause disease and mortality in fish are E. pisciphila (Fijan 1969, McGinnis \& Ajello 1974). E. psychrophila (Pedersen \& Langvad 1989), E. salmonis (Carmichael 1966), E. xenobiotica (Munchan et al. 2009), E. angulospora (Nyaoke et al. 2009), and a number of undescribed species (Alderman \& Feist 1985, S. de Hoog pers. comm.). Rearing under artificial conditions appears to create a predisposition for infection by opportunistic fungal pathogens. For example, mycoses due to E. angulospora and other Exophiala spp. have been frequently reported in aquaria-maintained weedy sea dragons from a number of locations in the United States (Nyaoke et al. 2009). Pathological changes in Exophiala-infected fish have 
been reported to be dominated by necrosis (Nyaoke et al. 2009), mononuclear leukocytes (Munchan et al. 2009), and inflammation characterised as granulomatous in different fish species (Carmichael 1966, Richards et al. 1978, Langvad \& Pedersen 1985, Kurata et al. 2008) including cod (Blazer \& Wolke 1979). Fungal diseases usually do not cause high short-term losses, but may yield high accumulated losses over time.

In the present study, we isolated Exophiala angulospora from clinically diseased cod maintained in indoor tanks and showed that the fungus caused severe inflammation and increased mortality of infected animals.

\section{MATERIALS AND METHODS}

Fish samples. In November 2005, cod of about 150 to $250 \mathrm{~g}$ originating from a farm in the western part of Norway were transferred to an indoor tank for experimental purposes. The tank was supplied with continuously flowing sea water. After a few months, increasing numbers of fish showed clinical signs of disease. This included abnormal swimming behaviour and dark coloration of the skin of the caudal part, which most fre- quently appeared with a sharp demarcation to unaffected areas. During April-May 2006, moderate mortality was observed. At the time of sampling in June 2006, about $50 \%$ of the fish showed clinical signs of disease.

On 2 occasions, 4 fish with clinical signs of disease were killed by a blow to the head, brought on ice to the laboratory, and necropsied the next day (Samplings 1 and 2; Table 1). Tissue samples, as indicated in Table 1, were collected and microbiological smears were made. Based on the results from these cases, an additional 4 fish with clinical signs of disease, including one with rotating swimming behaviour and 2 apparently healthy fish, were killed with an anaesthetic overdose, necropsied on site, and material collected, as indicated in Table 1 (Sampling 3). Tissues were also frozen at $-80^{\circ} \mathrm{C}$ for various analytical purposes. All fish samples used in the present study are listed in Table 1.

Histology. Tissue samples (Table 1), were fixed in neutral phosphate buffered $10 \%$ formalin, embedded in paraffin and $3 \mu \mathrm{m}$-thick sections were cut and stained with haematoxylin and eosin (H\&E). Additional selected sections were stained with periodic acid-Schiff (PAS) for sugar residues present in cell walls and other fungal structures. Additional sections

Table 1. Cod material used in the present study along with obtained isolates of Exophiala angulospora. Cod individuals were either moribund (M) or apparently healthy (AH). Tissues investigated include brain (B), kidney (K), liver (L), spleen (S) and skin (Sk). VI numbers refer to the assigned strain number of the pure culture isolate of $E$. angulospora in the culture collection Mykoteket at the Norwegian Veterinary Institute. Missing isolates are either results of no growth (NG) or no isolation attempt (-). EMBL/GenBank accession numbers are given for ITS-sequences of the pure culture isolates

\begin{tabular}{|c|c|c|c|c|c|}
\hline Sampling & Cod ID & $\begin{array}{l}\text { Organs for } \\
\text { histological } \\
\text { examination }\end{array}$ & $\begin{array}{c}\text { Gross anatomical } \\
\text { distribution of } \\
\text { mycotic lesions }\end{array}$ & $\begin{array}{c}\text { Exophiala angulospora } \\
\text { isolates }\end{array}$ & $\begin{array}{c}\text { GenBank } \\
\text { accession number }\end{array}$ \\
\hline 1 & 1.T1 (M) & $\mathrm{K}, \mathrm{L}, \mathrm{S}$ & $\mathrm{K}, \mathrm{S}$ & $\begin{array}{l}\text { VI } 04031 \text { (K) } \\
\text { VI } 04032 \text { (L) }\end{array}$ & $\begin{array}{l}\text { FR847107 } \\
\text { FR847108 }\end{array}$ \\
\hline 1 & 1.T2 (M) & - & $\mathrm{K}, \mathrm{S}, \mathrm{L}$ & - & - \\
\hline 1 & 1.T3 (M) & - & $\mathrm{K}, \mathrm{S}$ & - & - \\
\hline 1 & 1.T4 (M) & - & $\mathrm{K}, \mathrm{S}, \mathrm{L}$ & - & - \\
\hline 2 & 2.T1 (M) & $\mathrm{K}, \mathrm{L}, \mathrm{S}$ & $\mathrm{K}, \mathrm{L}$ & $\begin{array}{l}\text { VI } 03756(\mathrm{~K}) \\
\text { VI } 03757(\mathrm{Sk}) \\
\text { VI } 03758(\mathrm{~K})\end{array}$ & $\begin{array}{l}\text { FR847101 } \\
\text { FR847102 } \\
\text { FR847103 }\end{array}$ \\
\hline 2 & 2.T2 (M) & - & K & NG (K) & - \\
\hline 2 & 2.T3 (M) & $\mathrm{K}, \mathrm{L}, \mathrm{S}$ & $\mathrm{K}$ & VI 03759 (K) & FR847104 \\
\hline 2 & 2.T4 (M) & $\mathrm{K}, \mathrm{L}, \mathrm{S}$ & $\mathrm{K}, \mathrm{L}$ & $\begin{array}{l}\text { VI } 03760(\mathrm{~S}) \\
\text { VI } 03761(\mathrm{~K})\end{array}$ & $\begin{array}{l}\text { FR847105 } \\
\text { FR847106 }\end{array}$ \\
\hline 3 & 3.T1 (M) & $\mathrm{K}, \mathrm{L}, \mathrm{S}$ & $\mathrm{K}$ & $\mathrm{NG}^{\mathrm{b}}$ & - \\
\hline 3 & 3.T2 (M) & $\mathrm{K}, \mathrm{L}, \mathrm{S}$ & $\mathrm{K}, \mathrm{S}, \mathrm{M}$ & - & - \\
\hline 3 & 3.T3 $\left(\mathrm{M}^{\mathrm{a}}\right)$ & $\mathrm{K}, \mathrm{L}, \mathrm{S}, \mathrm{B}$ & $\mathrm{K}, \mathrm{S}, \mathrm{L}, \mathrm{B}$ & $\mathrm{NG}^{\mathrm{b}}$ & - \\
\hline 3 & 3.T4 (M) & $\mathrm{K}, \mathrm{L}, \mathrm{S}$ & $\mathrm{K}, \mathrm{S}$ & - & - \\
\hline 3 & 3.T5 (AH) & $\mathrm{K}, \mathrm{L}, \mathrm{S}$ & - & - & - \\
\hline 3 & 3.T6 (AH) & $\mathrm{K}, \mathrm{L}, \mathrm{S}$ & L & VI $05436^{b}(L)$ & $\begin{array}{l}\text { FR847109 } \\
\text { FR847110 } \\
\text { FR847111 }^{\mathrm{c}}\end{array}$ \\
\hline
\end{tabular}


of cod with inflammations due to infections with the bacteria Listonella anguillarum and atypical Aeromonas salmonicida were stained with PAS for the purpose of examining if inflammatory cells proved by nonfungal agents may contain positive material. Sections of the kidney of one fish were also stained with Martius scarlet blue (MSB) for detection of connective tissue fibers as described by Bancroft \& Stevens (1996). Pigmentation of hyphae was studied in one unstained section.

Isolation of fungi. For the cod sampling 1.T1, microbiological smears were made with sterile inoculation loops from the kidney and liver onto Sabouraud's medium (SAB: $10 \mathrm{~g} \mathrm{l}^{-1}$ neopeptone [Difco], $20 \mathrm{~g} \mathrm{l}^{-1} \mathrm{glu}-$ cose, $5 \mathrm{~g} \mathrm{l}^{-1}$ bacto yeast extract [Difco], $20 \mathrm{~g} \mathrm{l}^{-1}$ granulated agar [Difco], $1 \mathrm{ml} \mathrm{l}^{-1}$ chloramphenicol) adjusted to a $\mathrm{pH}$ of 6.0 to 6.5 . Isolation plates were incubated in darkness at $25^{\circ} \mathrm{C}$. This resulted in extensive growth of a darkly pigmented fungus. The internal organs from a second sampling of cod showing signs of disease (2.T1-T4) were therefore dissected aseptically, briefly surface sterilized in $70 \%$ ethanol for $30 \mathrm{~s}$, rinsed in sterile Milli-Q water, cut into $2 \mathrm{~mm}$ pieces, and plated onto SAB medium. The isolation plates were incubated in darkness at $25^{\circ} \mathrm{C}$. On-site isolation of fungi from the organs using microbiological smears of a third cod sampling (3.T1-T6) was attempted, but failed due to high levels of indoor fungal contaminants. Isolation of the fungus was therefore attempted from frozen organ material embedded in OCT-Tissue tek ${ }^{\circledR}$ medium (Chemi-teknik) according to the procedure described for 2.T1-T4. Additionally, $2 \mathrm{~mm}$ sub-samples of each organ were made for molecular analyses. From each isolation plate, one representative strain of the fungus that appeared pure culture was sub-cultured onto potato dextrose agar (PDA: $39 \mathrm{~g} \mathrm{l}^{-1}$ potato dextrose agar [Merck]) for further morphological and molecular characterization. The isolates are maintained in the culture collection Mykoteket at the Norwegian Veterinary Institute.

To determine possible sources of infection, water samples were collected superficially and approximately at $1 \mathrm{~m}$ depth in the tank as well as from the inlet water and examined as described by Hageskal et al. (2007). Briefly, $100 \mathrm{ml}$ from each water sample was filtered onto membrane filters that were transferred to dichloran $18 \%$ glycerol agar (DG18) plates (Hocking \& Pitt 1980) and incubated at $20 \pm 1^{\circ} \mathrm{C}$ for $2 \mathrm{wk}$. Colonyforming units (CFU) were enumerated weekly and expressed as CFU per $100 \mathrm{ml}$ water sample. Dominant genera and species were determined based on morphology. Samples of fish feed stored both indoors and outdoors were also screened quantitatively and qualitatively for fungi according to the NMKL method 98 (Nordic Committee on Food Analysis 2005). Briefly,
$40 \mathrm{~g}$ feed samples were added to $360 \mathrm{ml}$ unbuffered peptone water and homogenized in stomacher bags for 2 min. A dilution series to $10^{-4}$ was prepared, and $0.1 \mathrm{ml}$ of each dilution was plated on DG18 and incubated at $25 \pm 1^{\circ} \mathrm{C}$ for $1 \mathrm{wk}$. Quantitative results were expressed as CFU g ${ }^{-1}$ feed sample, and dominant genera and species were determined based on morphology. Plates were examined for several months to detect both fast- and slow-growing fungi.

Morphological characterization. The macroscopic morphology of the fungus was examined in 15 to $30 \mathrm{~d}$ old colonies on PDA. Mounts of 7 to $10 \mathrm{~d}$ old slidecultures grown on cereal agar (CA: $100 \mathrm{~g} \mathrm{l}^{-1}$ Pablum, $20 \mathrm{~g} \mathrm{l}^{-1}$ agar) were made in water, polyvinyl alcohol (PVA: $1.66 \mathrm{~g}$ polyvinyl alcohol in $10 \mathrm{ml}$ water), or PVA with acid fuchsin $(0.05 \mathrm{~g}$ acid fuchsin in $10 \mathrm{ml}$ lactic acid and $1 \mathrm{ml}$ glycerine mixed with $1.66 \mathrm{~g}$ polyvinyl alcohol dissolved in $10 \mathrm{ml}$ water). Light micrographs (LM) were made using a Leica DC100 digital camera.

Molecular identification. A total of 9 fungal isolates (Table 1) representing one isolation plate each were identified based on sequences from the nuclear ribosomal internal transcribed spacer region (ITS) including ITS1, 5.8S, and ITS2. DNA was extracted from a 2 to $3 \mathrm{~mm}$ slice of fresh mycelium using the CTAB-protocol described by Gardes \& Bruns (1993) with the modifications described in Vrålstad et al. (2009). The PCR reactions were run on a DNA Engine Tetrad ${ }^{\circledR}$ Peltier Thermal Cycler (PTC-225, MJ Research) using 1.7 $\mu \mathrm{M}$ of the primers ITS1 and ITS4 (White et al. 1990), $2 \mu \mathrm{l}$ genomic DNA, PuReTaq Ready-To-GoTM PCR Beads (Amersham Biosciences), and Milli-Q water to a final reaction volume of $25 \mu$ l. The PCR-program included an initial denaturation $\left(94^{\circ} \mathrm{C}\right.$ for $\left.4 \mathrm{~min}\right), 35$ cycles of amplification $\left(94^{\circ} \mathrm{C}\right.$ for $30 \mathrm{~s}, 55^{\circ} \mathrm{C}$ for $30 \mathrm{~s}, 72^{\circ} \mathrm{C}$ for $1 \mathrm{~min})$, and final elongation $\left(72^{\circ} \mathrm{C}\right.$ for $\left.5 \mathrm{~min}\right)$. DNA was also extracted from frozen organ tissues with the same procedure, but PCR and sequencing were performed using the fungal specific primer ITS1F (Gardes \& Bruns 1993) in combination with ITS4. The PCR products were visualized by gel electrophoresis on $1 \%$ agarose gels with ethidium bromide. PCR products were purified with ExoZap-IT (Amersham Biosciences) according to the manufacturer's protocol, and sequenced in both directions with their respective primers using the BigDye ${ }^{\circledR}$ Terminator version 3.1 Ready Reaction mix (Applied Biosystems) according to the manufacturer's instructions. The sequencing PCR-program consisted of initial denaturation $\left(96^{\circ} \mathrm{C}\right.$ for $\left.1 \mathrm{~min}\right)$ and 40 cycles of $96^{\circ} \mathrm{C}$ for $10 \mathrm{~s}, 56^{\circ} \mathrm{C}$ for $5 \mathrm{~s}$, and $60^{\circ} \mathrm{C}$ for $4 \mathrm{~min}$. The products were purified with BigDye ${ }^{\circledR}$ XTerminator Purification Kit (Applied Biosystems, Life Technologies) according to the manufacturer's instructions, and analyzed on an ABI PRISM ${ }^{\circledR} 3100$ Avant Genetic Analyzer (Applied Biosystems). Assembly and manual 
editing of the sequence chromatograms were conducted in BioEdit version 7.0.1 (Hall 1999). Table 1 includes the EMBL/GenBank accession numbers of sequenced fungal isolates of this study.

Phylogenetic analysis. The ITS sequences of Exophiala angulospora isolates from the present study, and other members of the genus Exophiala and its associated teleomorph, Capronia, were assembled in a data matrix that was aligned using MAFFT version 6.717 (Katoh \& Toh 2008). The subsequent alignment was manually verified, and the resulting matrices were subjected to maximum likelihood and Bayesian analyses. The Akaike information criterion in Modeltest (Posada \& Crandall 1998) was used to determine the best-fit model of evolution for both maximum likelihood and Bayesian analyses. Maximum likelihood analyses used to determine the most likely tree and maximum likelihood bootstrap support for each dataset were conducted using GARLI version 1.0 (Zwickl 2006) with the selected models of evolution implemented. Bayesian analyses were conducted using MrBayes version 3.1 (Huelsenbeck \& Ronquist 2001, Ronquist \& Huelsenbeck 2003), with 2 independent runs of four Markov Chain Monte Carlo chains with $1.0 \times 10^{7}$ generations each, sampling trees every 1000th generation. A final standard deviation $<0.01$ for the split frequency was taken as an indication that convergence had been achieved. The first $20 \%$ of sampled trees were discarded as burn-in and posterior probabilities for each node of the $50 \%$ majority rule consensus tree were recorded. All Modeltest, GARLI, and MrBayes analyses were performed at http://www. bioportal.uio.no.

\section{RESULTS}

\section{Gross pathology}

The clinically diseased fish had foci that ranged from a few $\mathrm{mm}$ to $2 \mathrm{~cm}$ and occurred in varying numbers in one or several organs such as the kidney (Fig. 1a), spleen, and liver (Fig. 1b), with the kidney being affected most frequently (Table 1). The foci were rounded with an indistinct border to adjacent tissue, and with a greyish to brownish colour on their external (Fig. 1b) and cut surfaces. In fish with dark coloration of the skin in the caudal part, pathological changes were detected in the caudal part of the kidney just cranial to the dark coloration. In one fish with dark coloration of the skin on one side of the head, an ipsilateral focus was found in the head kidney. The fish with rotating swimming behaviour had a small greyish area in the midbrain (Fig. 1c) and one apparently healthy fish had a focus in its liver.

\section{Histopathology}

The foci described above were dominated by light yellow to brown, septate, branched (Fig. 1d), and PASpositive fungal hyphae surrounded by inflammatory cells that were organised in distinct layers. Altogether, this created an invasive appearance (Fig. 1e). In the innermost layer, denoted Layer 1, there were many ramifying PAS-positive hyphae, arranged in a starshaped manner and surrounded by dead macrophage like (MLCs) (Fig. 2a,b). Layer 2 consisted of mostly MLCs with blastic nuclei, a few fungal hyphae (Fig. 2a), and a few flattened, concentrically arranged cells with condensed, elongated nuclei that are tentatively identified as fibrocyte-like cells (FLCs). A third peripheral layer included concentrically arranged FLCs (Fig. 2a) and the presence of collagen as indicated by MSB-staining. In some foci, we observed intra- and extracellular materials that stained homogenously for PAS (Fig. 2c). In the kidney of some fish, fungal hyphae were also detected in the excretory system and apparently invading the epithelium (Fig. 2d).

In the fish with rotating swimming behaviour, the small greyish area of the midbrain was located in the tectum opticum, and adjacent tissue contained hyphae and inflammatory cells. In the 2 apparently healthy fish, a few foci as described for the moribund fish were seen in the spleen and kidney or liver, respectively. Also, foci in control sections were layered in similar way, and PAS staining of material that was not consistent with fungus, was observed in Layer 2.

\section{Microbial cultivation and morphological identification}

Numerous uniform, black, slow-growing fungal colonies were obtained in pure culture from all but one of the isolation plates of foci from Samplings 1 and 2 (Table 1). Only indoor fungal contaminants were obtained from isolation plates that were inoculated onsite during Sample 3 (data not shown). However, fungal colonies that were morphologically identical to cultures from the other 2 samplings emerged in pure culture from the frozen liver tissue of one cod from that sampling (Table 1).

All isolates were consistent in morphology, producing floccose dark grey to olivaceous grey-brown colonies on PDA, attaining a diameter of $33 \mathrm{~mm}$ after $30 \mathrm{~d}$ (Fig. 3a) and becoming velvety with age. Conidiophores were darkly pigmented and branched or unbranched, bearing hyaline to pale olivaceous, flask-shaped to cylindric conidiogenous cells (Fig. 3b,c). Conidiation was annellidic, and also occurred occasionally at intercalary conidiogenus loci (Fig. 3d). Conidia were produced in 

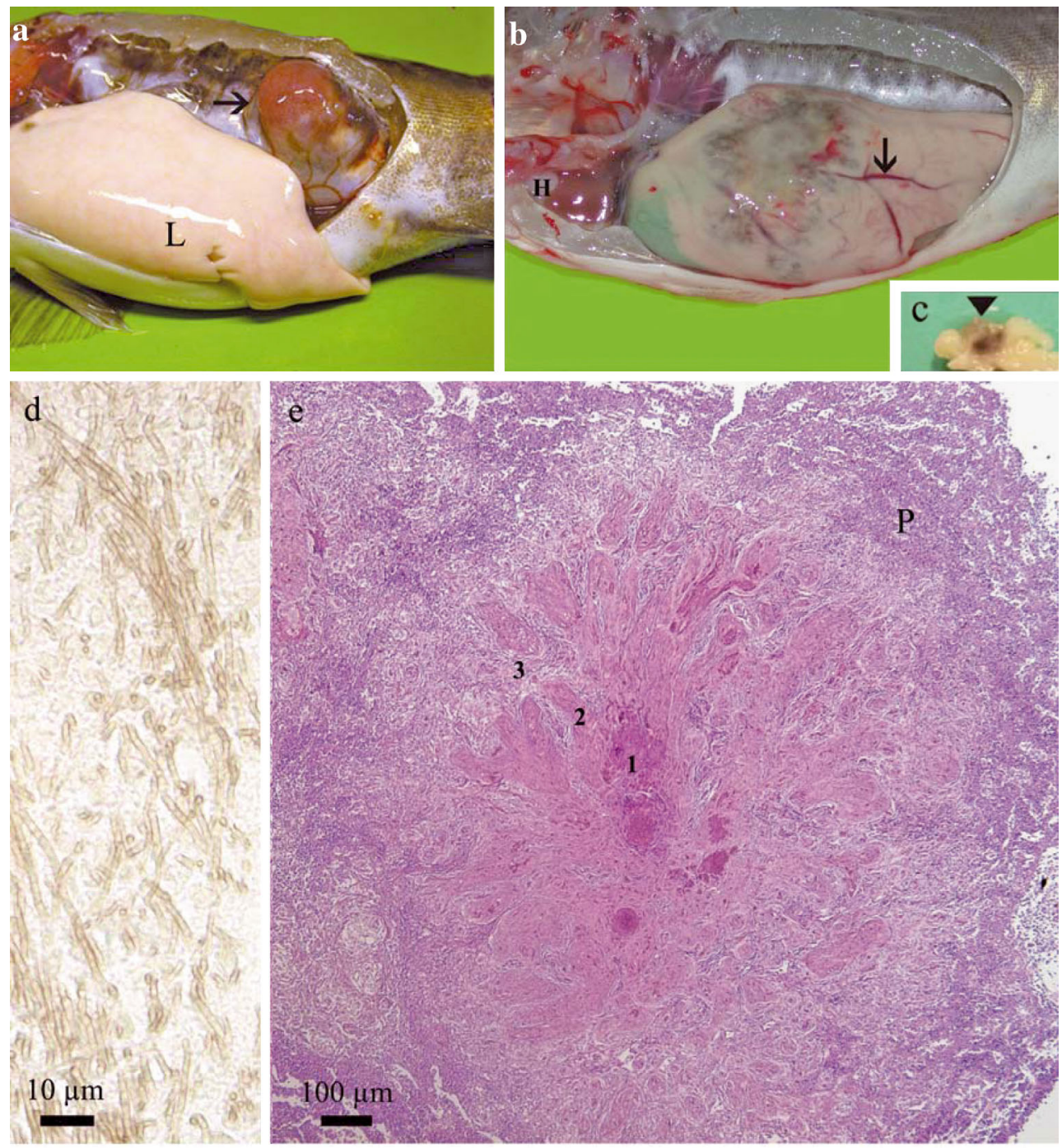

Fig. 1. Gadus morhua. Atlantic cod infected with Exophiala angulospora. (a-c) Gross pathology; (d,e) histological sections of kidney. (a) Large protruding focus in caudal part of kidney (arrow). L: liver. (b) Large greyish to brownish and partly greenish focus and blood-filled vessels in the liver (arrow). Note also the greenish color outside the focus in the most cranial part of the liver, as compared to normal colour in (a). H: heart. (c) Greyish to brownish focus affecting the whole tectum opticum of the midbrain (arrowhead). (d) Brownish hyphae in a focus. No stain. (e) Large, irregular and poorly-confined foci consisting of centrally-located hyphae and surrounded by inflammatory cells organized in distinct layers denoted layer 1, 2 and 3 as indicated. The invasiveness of hyphae in different directions has resulted in a ramified pattern of eosinophila due to dead cells around hyphae within the focus. Haematoxylin and eosin. P: parenchyma

masses, were single-celled, angular, or sometimes elliptic to subglobose, 2-4(-8) $\times 1.5-3 \mu \mathrm{m}$ (Fig 3e). The diagnostic angular conidia allowed the morphological identification of the fungus as Exophiala angulospora.

Exophiala angulospora was not recovered from any of the water or feed samples. These were instead dominated by the genera Penicillium and Cladosporium in numbers that, at least in some samples, may indicate reduced hygienic quality of the water and feed (Table 2). The water and feed plates were also quickly overgrown, which in general hampers the detection of slower-growing fungal taxa.

\section{Molecular identification and phylogeny}

The sequenced isolates, one representative from each isolation plate, were in all cases identified as 99 to $100 \%$ similar across the ITS region to Exophiala angulospora and $99 \%$ similar to its sexual stage, Capronia coronata. The aligned matrix of ITS sequences included 495 characters for the 214 sequences representing 32 species of Exophiala and Capronia. The SYM+I+G model was selected by ModelTest as the best-fit model of evolution for the data and was implemented in both maximum likelihood and Bayesian inference analyses. 

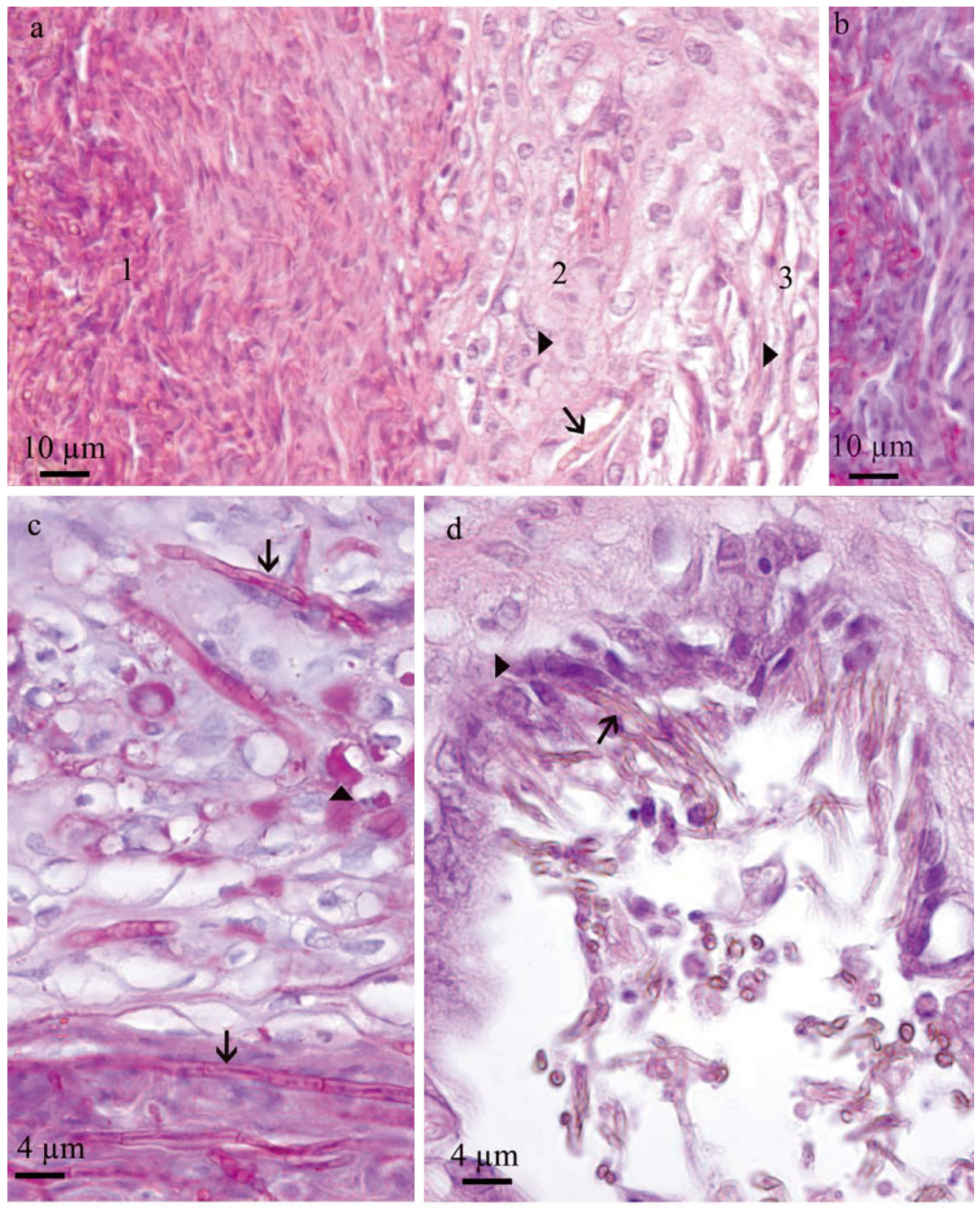

Fig. 2. Gadus morhua. Atlantic cod infected with Exophiala angulospora. Histological sections of (a-b) kidney interstitium, (c) liver, and (d) a kidney tubule or duct, stained with (a,d) H\&E and (b,c) periodic acid-Schiff (PAS). (a) Layer 1; note the high number of hyphae and dead cells (1). Many macrophage-like cells with blastic nuclei (left arrowhead) and and a single hyphae (arrow) are seen in layer 2. Flattened fibrocyte-like cells are seen in layer 3 (right arrowhead). (b) PAS-positive hyphae in layer 1. (c) Some hyphae are seen in layer 1 (lower arrow) and layer 2 (upper arrow). Note branched and septate structure, and some material of unknown nature in putative inflammatory cells staining homogenously for PAS (arrowhead). (d) Many hyphae (arrow) apparently invading from the lumen into the epithelium of a kidney tubule or duct (arrowhead)

The maximum likelihood tree with results of both maximum likelihood and Bayesian inference is shown in Fig. 4. Our isolates of E. angulospora form a monophyletic group with C. coronata and other isolates of $E$. angulospora from fish, drinking water, human, soil, and plant substrates $(100 \%$ Bayesian Posterior Probability
[BPP] / 97\% Bootstrap Support [BS]). The E. angulospora / C. coronata clade is well resolved from all other Exophiala and Capronia species, including those previously reported as pathogens of fish: E. salmonis, E. pisciphila, E. xenobiotica and a currently unnamed species Exophiala sp. 7 in Fig. 4. 


\section{DISCUSSION}

This is to our knowledge the first documentation of systemic mycosis in Atlantic cod caused by Exophiala angulospora. The fungal species, identified by using morphological characteristics and ITS sequence analyses, was isolated in pure culture from numerous foci of diseased fish. Since no other agents were detected and the morphology of fungus in sections was consistent with the observed cultures, there is little doubt that the inflammations were associated with the isolated fungus. As demonstrated by our repeated isolation of E. angulospora from foci of diseased fish, the species is easily cultured, and can readily be identified based on morphology by its characteristic more or less triangular conidia. Our phylogenetic analyses show that E. angulospora is genetically distinct from all other species of Exophiala that so far have been associated with dis-
Table 2. Cultivation results from water and feed samples given in colony forming units (CFU) of fungi per $100 \mathrm{ml}$ and $1 \mathrm{~g}$, respectively. Colonies of filamentous fungi were, when possible, identified to genus level. No attempts were made to identify dematiaceous fungi to genus level, but it was verified that these did not include any Exophiala spp. Yeasts were not identified any further. LOD: limit of detection

\begin{tabular}{|c|c|c|}
\hline Sample & Result & Fungal group \\
\hline Water superficial & $100 \mathrm{CFU} 100 \mathrm{ml}^{-1}$ & Penicillium simplicissimum \\
\hline Water deep & 5 CFU $100 \mathrm{ml}^{-1}$ & Penicillium spp. \\
\hline Water deep & $1 \mathrm{CFU} 100 \mathrm{ml}^{-1}$ & Dematiaceous fungi \\
\hline Water deep & $1 \mathrm{CFU} 100 \mathrm{ml}^{-1}$ & Other yeasts \\
\hline Inlet water & $14 \mathrm{CFU} 100 \mathrm{ml}^{-1}$ & Penicillium spp. \\
\hline Inlet water & $2 \mathrm{CFU} 100 \mathrm{ml}^{-1}$ & Cladiosporium spp. \\
\hline Inlet water & $1 \mathrm{CFU} 100 \mathrm{ml}^{-1}$ & Dematiaceous fungi \\
\hline Feed stored outside & Below LOD & Filamentous fungi and yeast \\
\hline Feed stored inside & $2300 \mathrm{CFU} \mathrm{g}^{-1}$ & Penicillium spp. \\
\hline Feed stored inside & $110000 \mathrm{CFU} \mathrm{g}^{-1}$ & Yeast \\
\hline
\end{tabular}
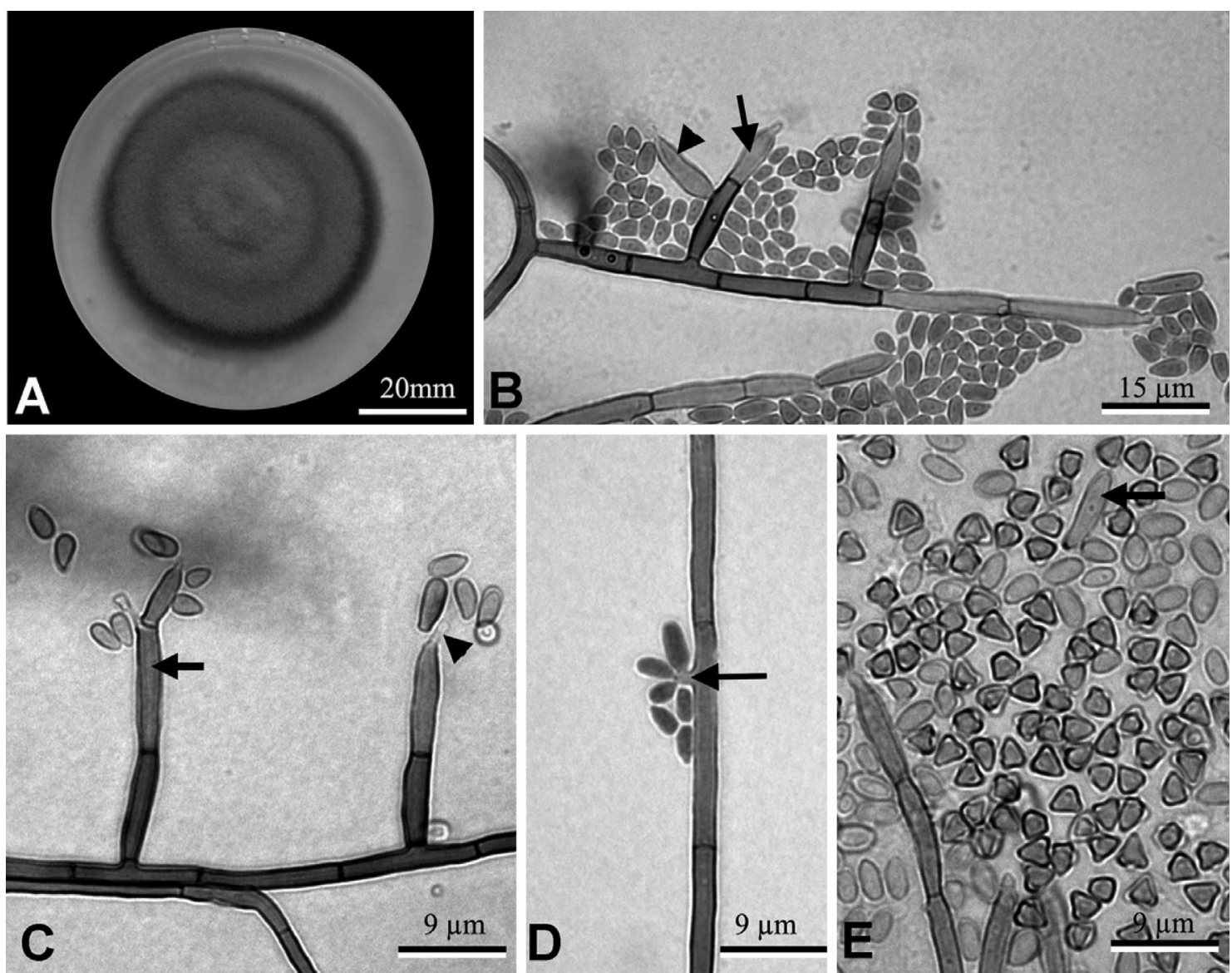

ease in fish, and can be reliably identified using molecular means and the ITS gene region for fungal barcoding. Since our isolates of E. angulospora from dis- 


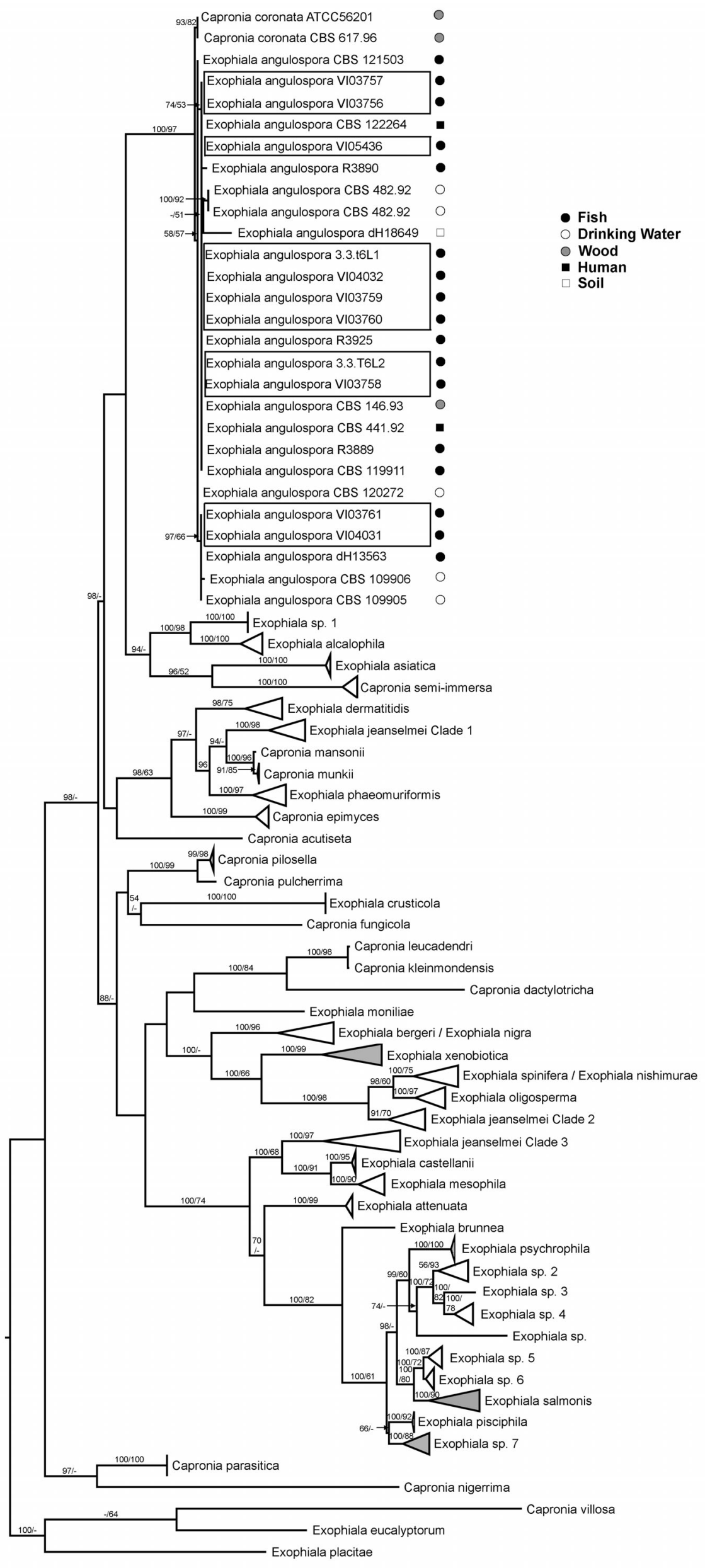


Fig. 4. Maximum likelihood tree (-lnL 13330.46) inferred from analysis of ITS sequences showing the placement of Exophiala angulospora among members of Exophiala and Capronia. C. villosa, E. eucalyptorum, and E. placitae serve as outgroup taxa. Strain names are indicated after species of E. angulospora, and accession numbers or strain numbers for sequences used in this analysis are available in Table S1 in the supplement at www.int-res.com/articles/suppl/d096p209_supp.pdf. Bootstrap values $>50 \%$ calculated from 1000 replicates and Bayesian posterior probabilities $>50$ are given above the branches as Bayesian posterior probability/bootstrap proportion. Gaps (-) indicate a collapsed node in an analysis. Clades previously reported as opportunistic pathogens of fish are marked in grey. Sequences derived from isolates in this study are indicated by boxes. The substrate from which each strain of $E$. angulospora was isolated is indicated by the symbols after the species and strain names

eased fish cannot be separated from isolates obtained from other substrates such as wood and water, at least not with the currently used genetic marker, it is likely that E. angulospora is an opportunistic pathogen not restricted to a pathogenic life history.

Species of Exophiala are known to produce a variety of extracellular enzymes, including ureases, gelatinases, and lipases (De Souza et al. 2008, Corbellini et al. 2009). Effects of extracellular enzymes on fish host cells may explain why dead cells were observed in layer 1 of the foci where abundant fungal hyphae were present, but not in the layers containing few hyphae. By comparison, in weedy sea dragons infected with $E$. angulospora, the predominant pathological change was described as necrosis (Nyaoke et al. 2009). Hence, differences in pathological manifestations may reflect different host responses, rather than variability in the fungus. This is further supported by the phylogenetic analyses where isolates of E. angulospora from different hosts did not form distinct, well-supported subgroupings. However, it is also well known that both morphology and ITS poorly resolve species in fastevolving lineages of ascomycetes including plant and animal pathogenic species (see Balajee et al. 2009). It remains therefore to test the validity of this hypothesis by multi-locus sequence analyses of genetic markers that have proved more variable than ITS for many important groups of ascomycetes, e.g. EF-1 $\alpha$ (translation elongation factor $1 \alpha$ ), $\beta$-TUB ( $\beta$-tubulin), and CAM (calmodulin), and RPB2 (RNA polymerase II second largest subunit; Balajee et al. 2009).

A granulomatous inflammation, with distinct layers of inflammatory cells, as seen in the present study, has not been previously reported in Exophila angulospora infections of fish. However, it has been reported from captive cod infected with an Exophila-like fungus (Blazer \& Wolke 1979) and in cod suffering from bacterial diseases (Magnadottir et al. 2002, Gudmundsdottir et al. 2006). It is unclear if the homogenous PAS-positive material observed in areas of foci originates from the fungi (i.e. represents phagocytosed fungal parts). Similar homogenously PAS-stained material was also observed in the control foci caused by atypical Aeromonas salmonicida, indicating that at least some of the PAS-positive material may originate from the inflammatory cells.
The production of melanin has been considered an important virulence factor of fungi, including Exophiala species, and mutant albino strains of E. dermatitidis have been shown to have lower virulence than wildtype melanized strains (De Hoog et al. 2000). More specifically, melanin has been shown to play a crucial role in allowing $E$. dermatitidis to survive oxidative bursts within the phagolysosome of mammalian neutrophils that could otherwise protect the host from this pathogen (Schnitzler et al. 1999). The growth of the darkly pigmented fungus in the present study was clearly invasive with ineffective restriction by the inflammatory response. The success of E. angulospora in overcoming host defence to infection may therefore partly be attributed to its melanized hyphae that have been documented to exert larger turgor-derived forces at their apices than non-melanized cells (Brush \& Money 1999). Given the large amounts of fungal hyphae observed in the internal organs, and the absence of pigmented host cells, we conclude that the discoloration of the fishes' internal organs can be attributed to fungal pigments. The dark discoloration of skin caudal to foci is similar to that observed in fish infected with Myxobolus cerebralis (Speare \& Salvatore 2006), and can probably be explained by lesions affecting spinal nerves innervating skin chromatophores (Whitear 1952).

To the best of our knowledge, there are no established upper values of acceptable amounts of Penicillium simplicissimum in indoor marine aquaria. However, we assume that the amounts of $P$. simplicissimum detected in the superficial water samples exceeds what can be expected in similar facilities, and may therefore suggest reduced water quality. Further, it cannot be excluded that the Penicillium levels in the water may have negatively impacted the immune system of the fish, and, combined with the additional stress of being transferred and maintained in an indoor tank, predisposed them to opportunistic infection by Exophiala angulospora. Although Exophiala infections have been reported in increasing numbers in healthy humans ( $\mathrm{Li}$ et al. 2011), they are traditionally reported in immunocompromised individuals (Sughayer et al. 1991). The source of E. angulospora inoculum responsible for this observed mycotic outbreak in Atlantic cod was not resolved in the present study. It is not clear if E. angu- 
lospora was absent in our analyses of feed and water or not detected due to biases in the culturing methods. However, we cannot rule out the possibility that the fish were infected with $E$. angulospora prior to their arrival at the indoor tanks, given the extensive and chronic changes in some individuals. E. angulospora and Capronia coronata, the putative sexual stage of the fungus judged from the ITS sequence similarity, have been reported from water, decorticated wood, human skin and nail, hydrocarbon polluted soils, as well as diseased fish (Müller et al. 1987, S. de Hoog pers. comm.), suggesting the fungus is widely distributed and the source of infection may be difficult or impossible to pinpoint.

The route by which Exophiala angulospora infected the fish remains unknown. However, the hyphae apparently growing from tubuli lumina into the epithelium could indicate an ascending infection to the kidney. This could also be supported by the fact that the kidneys were infected in all diseased fish.

Based on the pathological, cultural, and molecular evidence presented in the present study, we conclude that Exophiala angulospora caused the observed chronic multifocal granulomatous inflammation in internal organs of cod, resulting in severe disease and mortality. Further studies should include challenge experiments of E. angulospora on cod and salmonids to investigate and compare the portal of entry, pathogenesis, and host response.

Acknowledgements. This work was funded by the Norwegian Research Council (NFR project 173498). We thank Dr. Sybren de Hoog for his kind contribution of additional sequences for our phylogenetic analyses and discussion of the species limits of Exophiala angulospora. We also appreciate the advice and technical contributions provided by Even Thoen, Elin Rolén, Ellen Christensen and Randi Terland and colleagues from the Norwegian Veterinary Institute (NVI) and Torunn Taksdal (NVI) for constructive comments.

\section{LITERATURE CITED}

Alderman DJ, Feist SW (1985) Exophiala infection of kidney of rainbow trout recovering from proliferative kidney disease. Trans Br Mycol Soc 84:157-159

Balajee SA, Borman AM, Brandt ME, Cano J and others (2009) Sequence-based identification of Aspergillus, Fusarium, and Mucorales species in the clinical mycology laboratory: Where are we and where should we go from here? J Clin Microbiol 47:877-884

Bancroft JD, Stevens A (1996) Theory and practice of histological techniques. Churchill Livingstone, Edinburgh

Blazer VS, Wolke RE (1979) An Exophiala-like fungus as the cause of a systemic mycosis of marine fish. J Fish Dis 2: 145-152

Brush L, Money NP (1999) Invasive hyphal growth in Wangiella dermatitidis is induced by stab inoculation and shows dependence upon melanin biosynthesis. Fungal Genet Biol 28:190-200
Carmichael JW (1966) Cerebral mycetoma of trout due to Phialophora-like fungus. Sabouraudia 6:120-123

Corbellini VA, Scroferneker ML, Carissimi M, Da Costa JM, Ferrao MF (2009) Lipolytic activity of chromoblastomycosis agents measured by infrared spectroscopy and chemometric methods. Med Mycol 47:63-69

> De Hoog GS, Queiroz-Telles F, Haase G, Fernandez-Zeppenfeldt $\mathrm{G}$ and others (2000) Black fungi: clinical and pathogenic approaches. Med Mycol 38:243-250

De Souza TF, Scroferneker ML, Da Costa JM, Carissimi M, Corbellini VA (2008) Secretion of five extracellular enzymes by strains of chromoblastomycosis agents. Inst Med Trop S Paul 50:269-272

Domsch KH, Gams W, Anderson TH (2007) Compendium of soil fungi, 2nd edn. IHW-Verlag, Eching

Fijan N (1969) Systemic mycosis in channel catfish. Bull Wildl Dis Assoc 5:109-110

Gardes M, Bruns TD (1993) ITS primers with enhanced specificity for basidiomycetes - application to the identification of mycorrhizae and rusts. Mol Ecol 2:113-118

Gudmundsdóttir BK, Björnsdóttir B, Gudmundsdóttir S, Bambir SH (2006) A comparative study of susceptibility and induced pathology of cod, Gadus morhua (L.), and halibut, Hippoglossus hippoglossus (L.), following experimental infection with Moritella viscosa. J Fish Dis 29:481-487

Hageskal G, Gaustad P, Heier BT, Skaar I (2007) Occurrence of moulds in drinking water. J Appl Microbiol 102: $774-780$

Hall TA (1999) BioEdit: a user-friendly biological sequence alignment editor and analysis program for Windows 95/98/NT. Nucleic Acids Symp Ser 41:95-98

> Hocking AD, Pitt JI (1980) Dichloran-glycerol medium for enumeration of xerophilic fungi from low-moisture foods. Appl Environ Microbiol 39:488-492

Huelsenbeck JP, Ronquist F (2001) MRBAYES: Bayesian inference of phylogeny. Bioinformatics 17:754-755

Katoh K, Toh H (2008) Recent developments in the MAFFT multiple sequence alignment program. Brief Bioinform 9: 286-298

Kurata O, Munchan C, Wada S, Hatai K, Miyoshi Y, Fukuda Y (2008) Novel Exophiala infection involving ulcerative skin lesions in Japanese flounder Paralichthys olivaceus. Fish Pathol 43:35-44

Langvad F, Pedersen O (1985) A fungal disease caused by Exophiala sp. nova in farmed atlantic salmon in western Norway. In: Ellis AE (ed) Fish and shellfish pathology. Academic Press, London, p 323-328

Li DM, Li RY, De Hoog GS, Sudhadham M, Wang DL (2011) Fatal Exophiala infections in China, with a report of seven cases. Mycoses 54:136-142

Magnadóttir B, Bambir SH, Gudmundsdóttir BK, Pilström L, Helgason S (2002) Atypical Aeromonas salmonicida infection in naturally and experimentally infected cod, Gadus morhua L. J Fish Dis 25:583-597

McGinnis MR, Ajello L (1974) A new species of Exophiala isolated from channel catfish. Mycologia 66:518-520

> Müller E, Petrini O, Fischer PJ, Samuels GJ, Rossman AY (1987) Taxonomy and anamorphs of the Herpotrichiellaceae with notes on generic synonymy. Trans Br Mycol Soc 88:63-74

> Munchan C, Kurata O, Wada S, Hatai K, Sano A, Kamei K, Nakaoka N (2009) Exophiala xenobiotica infection in cultured striped jack, Pseudocaranx dentex (Bloch \& Schneider), in Japan. J Fish Dis 32:893-900

Nordic Committee on Food Analysis (NMKL) 98 (2005) Mould and yeasts. Determination in foods and feed, 4th edn. www.nmkl.org/Engelsk/index.htm. 
Nyaoke A, Weber ES, Innis C, Stremme D and others (2009) Disseminated phaeohyphomycosis in weedy seadragons (Phyllopteryx taeniolatus) and leafy seadragons (Phycodurus eques) caused by species of Exophiala, including a novel species. J Vet Diagn Invest 21:69-79

Orélis-Ribeiro R, Boeger WA, Vincente VA, Chammas M, Ostrensky A (2010) Fulfilling Koch's postulates confirms the mycotic origin of lethargic crab disease. Antonie van Leeuwenhoek 99:601-608

Otis EJ, Wolke RE, Blazer VS (1985) Infection of Exophiala salmonis in Atlantic salmon (Salmo salar L.). J Wildl Dis 21: 61-64

Pedersen OA, Langvad F (1989) Exophiala psychrophila sp. nov, a pathogenic species of the black yeasts isolated from farmed Atlantic salmon. Mycol Res 92:153-156

Posada D, Crandall KA (1998) MODELTEST: testing the model of DNA substitution. Bioinformatics 14:817-818

Richards RH, Holliman A, Helgason S (1978) Exophiala salmonis infection in Atlantic salmon Salmo salar L. J Fish Dis 1:357-368

Roberts RJ (2004) The mycology of teleosts. In: Roberts RJ (ed) Fish pathology. W.B. Saunders, Edinburgh, p 332-347

Ronquist F, Huelsenbeck JP (2003) MrBayes 3: Bayesian phylogenetic inference under mixed models. Bioinformatics 19:1572-1574

Schnitzler N, Peltroche-Llacsahuanga H, Bestier N, Zundorf J, Lutticken R, Haase G (1999) Effect of melanin and carotenoids of Exophiala (Wangiella) dermatitidis on

Editorial responsibility: David Bruno,

Aberdeen, UK phagocytosis, oxidative burst, and killing by human neutrophils. Infect Immun 67:94-101

Speare D, Salvatore F (2006) Nervous system. In: Ferguson HW (ed) Systemic pathology of fish. Scotian Press, London, p 219-243

Sughayer M, Degirolami PC, Khettry U, Korzeniowski D, Grumney A, Pasarell L, McGinnis MR (1991) Human infection caused by Exophiala pisciphila-case-report and review. Rev Infect Dis 13:379-382

Uijthof JMJ, Figge MJ, De Hoog GS (1997) Molecular and physiological investigations of Exophiala species described from fish. Syst Appl Microbiol 20:585-594

Vrålstad T, Knutsen AK, Tengs T, Holst-Jensen A (2009) A quantitative TaqMan (R) MGB real-time polymerase chain reaction based assay for detection of the causative agent of crayfish plague Aphanomyces astaci. Vet Microbiol 137: $146-155$

Whitear M (1952) The innervation of the skin of teleost fishes. J Cell Sci 93:289-305

White TJ, Bruns T, Lee S, Taylor J (1990) Amplification and direct sequencing of fungal ribosomal RNA genes for phylogenetics. In: Innis MA, Gelfand DH, Sninsky JJ, White TJ (eds) PCR protocols: a guide to methods and applications. Academic Press, New York, NY, p 315-322

Zwickl DJ (2006) Genetic algorithm approaches for the phylogenetic analysis of large biological sequence datasets under the maximum likelihood criterion. PhD thesis, The University of Texas at Austin

Submitted: April 11, 2011; Accepted: June 3, 2011

Proofs received from author(s): September 7, 2011 